\title{
ELECTROCHEMICAL AND MORPHOLOGICAL STUDY OF Zn-Mn ALLOYS DEPOSITED FROM BORIC ACID ELECTROLYTE ONTO THE CARBON STEEL FOR CORROSION PROTECTION
}

\author{
M. Y. Haciibrahimoğlu ${ }^{1}$, A. Yavuz ${ }^{2}$ \\ ${ }^{1}$ Department of Metallurgical and Materials Engineering, Gaziantep University, Sehitkamil, 27310, Gaziantep, \\ Turkey \\ ${ }^{2}$ Department of Metallurgical and Materials Engineering, Gaziantep University, Sehitkamil, 27310, Gaziantep, \\ Turkey
}

\begin{abstract}
Boric acid electrolyte was used for the deposition of zinc and $\mathrm{Zn}$-Mn films from the electrolyte having variable $\mathrm{pH}$ onto carbon steel substrate. The deposition and dissolution mechanisms of the Zn-Mn alloys were explained. The coatings were obtained potentiostatically by applying $-1.5 \mathrm{~V}$, then the morphological and corrosion behaviours of resulting films were studied. There was no reduction of manganese in acidic or neutral borate solution; hence, the coating from these solutions contained only zinc metal. The film obtained from alkaline borate electrolyte was Zn-Mn alloy including around 5wt. \% manganese. Zn-Mn alloy is in the form of amorphous structure and only zinc coatings have well crystalline structure. While chloride solution is accelerated the pitting corrosion on steel surface, coated steel (with either $\mathrm{Zn}$ or $\mathrm{Zn}-\mathrm{Mn}$ films) from borate based solution, is prevented from pitting corrosion as passivation of modified electrodes occurs in artificial seawater (3.5wt. \% aqueous $\mathrm{NaCl}$ solution). Corrosion rate of bare steel is higher than that of the modified electrodes. Electrodeposition of $\mathrm{Zn}$ and $\mathrm{Zn}$-Mn films from boric acid solution can not only protect steel from pitting corrosion but also give higher corrosion resistivity.
\end{abstract}

Keywords: Zinc-Manganese Alloy, Electrodeposition, Boric Acid Electrolyte, Amorphous Structure, Corrosion, Passivation

\section{INTRODUCTION}

Alloy coatings are deposited onto metals to protect bulk materials against corrosion. Lubricant, gaseous and liquid environments cause performance and lifetime reduction [1]. Corrosion resistance of steels is an important parameter in engineering design as steel is widely used by engineering applications. Steel surface has not sufficient corrosive resistance in aggressive medium [2]. Therefore, the electrodeposited coatings of alloys are aimed to be used as passive protection for steel in long term [3]. Zinc and zinc based alloys are widely used by industry for passive films e.g. using in galvanization process. Several research reported that zinc based alloy coatings such as $\mathrm{Zn}-\mathrm{Fe}$ [4], $\mathrm{Zn}-\mathrm{Ni}$ [5], Zn-Cu [6], Zn-Mn[7] and Zn-Co [8], show good corrosion resistivity. There are several research pointed towards the superior anticorrosion behaviour of $\mathrm{Zn}-\mathrm{Mn}$ alloys, which is attributed to the formation of a passive layer of both zinc and manganese oxides, which prevent oxygen reduction at the metallic surface $[9,10]$. Zn-Mn films were electrodeposited from various electrolyte including ionic liquids [11] or aqueous media (gluconate [12], pyrophosphate [13], sulphate-citrate [14], chloride [15] and selenite [16] based complex agents). Environmentally friendly electrolytes are focused on for alloy deposition [17]. The ligand in the deposition baths also affects the deposition potentials of the components in alloys as well as structural behaviour[18]. Among environmentally friendly electrolytes, borate based bath is an attractive ligand to obtain alloy coatings [19]. In this study, borate based electrolyte is used to electrodeposit Zn-Mn alloy. Although several studies regarding electrochemical deposition and structural characterization of $\mathrm{Zn}-\mathrm{Mn}$ alloys have been conducted [3,11, 13, 17], preparation and characterization of $\mathrm{Zn}-\mathrm{Mn}$ in boric acid having different $\mathrm{pH}$ values have not been studied. This article fills up this gap. The main objective of this study is to determine the anti-corrosive effect of $\mathrm{Zn}-\mathrm{Mn}$ onto carbon steel with variable $\mathrm{pH}$ of deposition bath. To do this potentiodynamic data of for the coatings are collected. Second objective of this work is to understand the electrochemical mechanism of the alloy deposition onto the carbon steel. The third one is to explore the structure of the films deposited with different $\mathrm{pH}$ of borate media.

\section{EXPERIMENTAL}

The solutions for the experiments given in this paper were prepared from chemicals supplied by Merck and Sigma Aldrich with distilled water without any purification. $50 \mathrm{mM}$ $\mathrm{ZnSO}_{4}$ and $50 \mathrm{mM} \mathrm{MnSO}_{4}$ compounds were added into a solution containing $50 \mathrm{mM}$ boric acid solution. The concentration of $\mathrm{Zn}^{2+}$ and $\mathrm{Mn}^{2+}$ in the background electrolyte is constant. However, $\mathrm{pH}$ of electrolyte was varied as shown in Table 1. $\mathrm{pH}$ of the media is adjusted by 1 $\mathrm{M} \mathrm{KOH}$ or $1 \mathrm{M} \mathrm{HCl}$. 
Table 1: Chemical contents and $\mathrm{pH}$ of deposition electrolytes.pH of the electrolytes are adjusted by dropping solution of $1 \mathrm{M} \mathrm{KOH}$ or $1 \mathrm{M} \mathrm{HCl}$ into deposition bath.

\begin{tabular}{|l|l|l|l|l|}
\hline Solution & $\begin{array}{l}\mathrm{Zn}\left(\mathrm{SO}_{4}\right)_{2} \\
(\mathrm{mM})\end{array}$ & $\begin{array}{l}\mathrm{Mn}\left(\mathrm{SO}_{4}\right)_{2} \\
(\mathrm{mM})\end{array}$ & $\begin{array}{l}\mathrm{H}_{3} \mathrm{BO}_{3} \\
(\mathrm{mM})\end{array}$ & $\mathrm{pH}$ \\
\hline Acidic & 50 & 50 & 50 & 4.08 \\
\hline Neutral & 50 & 50 & 50 & 7.12 \\
\hline Alkaline & 50 & 50 & 50 & 10.2 \\
\hline
\end{tabular}

A three-electrode system was used for deposition. The same system was also used to study electrochemical mechanism with cyclic voltammetric function and corrosion behaviours of the surface with linear sweep voltammetry function. A carbon steel (AISI 4140) working electrode has $1 \mathrm{~cm}$ diameter with one side covered with Bakelite.Pt working electrode (its diameter is $3 \mathrm{~mm}$ ) was used to elucidate the mechanism of the deposition and stripping of the film. The auxiliary and reference electrodes were $\mathrm{Ir} / \mathrm{Ru}$ mesh $\left(4 \mathrm{~cm}^{2}\right)$ and $\mathrm{Ag} / \mathrm{AgCl}$ (sat. $\mathrm{KCl}$ ), respectively. All the potentials shown here were referred to $\mathrm{Ag} / \mathrm{Ag}^{+}$reference electrode.

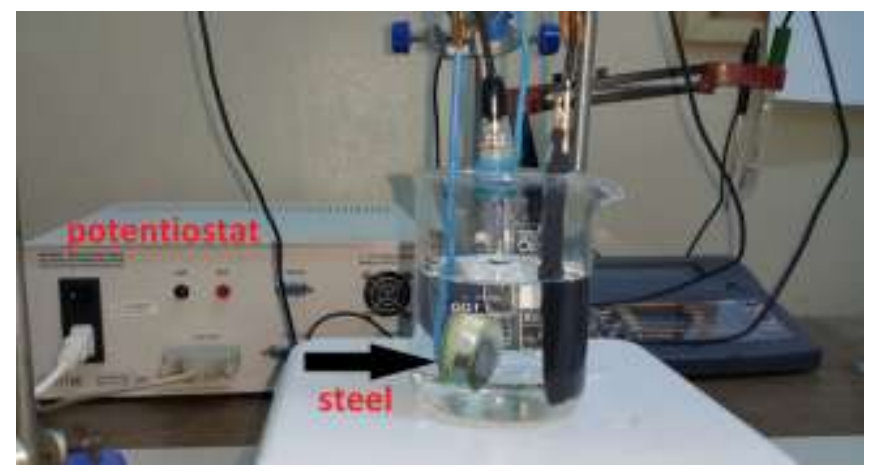

Fig-1: Photo of set-up for deposition of metals (alloys) and polarization characterisation of resulting films in $3 \mathrm{wt} \% \mathrm{NaCl}$ aqueous solution.

Before the deposition of the films, carbon steel surface was mechanically polished until obtaining a mirror shine surface by using appropriate sandpapers having grid size varied from 200 to 3000 then rinsed with deionised water. The electrochemical experiments were conducted in a CHI 1100 potentiostat (CHI Ins., the USA). All the coatings were electrodeposited potentiostatically by applying $-1.5 \mathrm{~V}$ for 300 seconds. After deposition the films were transferred to $3 \mathrm{wt} \% \mathrm{NaCl}$ in order to examine the corrosion resistivity of the films. All experiments were carried out at room temperature $(21 \pm 1)$. The elemental analysis of the films was studied by scanning electron microscope JEOL 6400 (with energy dispersive spectrometer carrying out between 15 and $30 \mathrm{kV}$ ).

\section{RESULTS}

\subsection{Deposition of $\mathrm{Zn}-\mathrm{Mn}$ Alloys}

The electrochemical growth of Zn-Mn alloys in borate media are studied by the cyclic voltammetry shown in Figure 2.

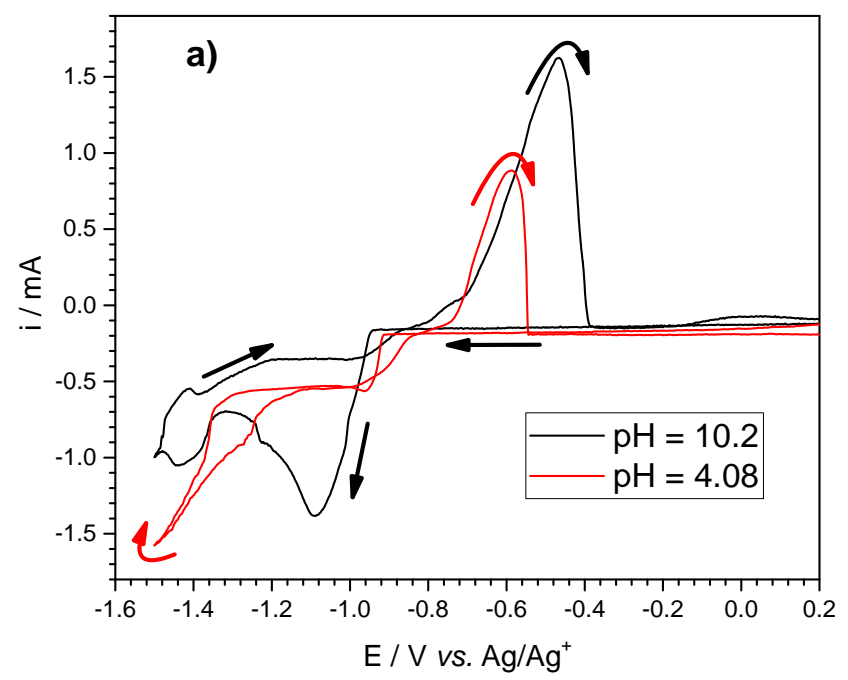

Fig-2: Cylic voltammogram of $50 \mathrm{mM} \mathrm{ZnSO}_{4}+50 \mathrm{mM}$ $\mathrm{MnSO}_{4}$ in $50 \mathrm{mM} \mathrm{H}_{3} \mathrm{BO}_{3}$. CV data are recorded for the Pt working electrode at a scan rate of $50 \mathrm{mV} \mathrm{s}^{-1}$.

The zinc and manganese reduction and deposition have been studied in different media, however the deposition of $\mathrm{Zn}-\mathrm{Mn}$ alloys in borate media has not been studied in detail. As there is no redox reaction of $\mathrm{Pt}$ working electrode between the potential windows of $-1.5 \mathrm{~V}$ and $0.2 \mathrm{~V}$ given in Figure 2, the Pt substrate is used as working electrode. Steel working electrode cannot be used for this potential window because $\mathrm{Fe}$ is oxidised in borate solution and results could not be interpreted in terms of $\mathrm{Zn}-\mathrm{Mn}$ alloys. The starting potential was $0.2 \mathrm{~V}$ in which there is no current flow. Black line of Figure 2 regarding alkaline borate electrolyte shows that there is no reduction until $-0.95 \mathrm{~V}$. There are three reduction peaks at around $-1.12 \mathrm{~V},-1.25 \mathrm{~V}$ and $-1.44 \mathrm{~V}$. A reduction peak commencing at $-0.95 \mathrm{~V}$ is due to the reduction of $\mathrm{Zn}^{2+}$ to $\mathrm{Zn}^{+}$. There is no conversion from $\mathrm{Zn}^{2+}$ to solid zinc $\left(\mathrm{Zn}^{0}\right)$. It cannot be directly from $\mathrm{Zn}^{2+}$ to $\mathrm{Zn}^{0}$ because there was no film when $-1.0 \mathrm{~V}$ was applied to this solution. The second peak around $-1.25 \mathrm{~V}$ is either the reduction of manganese or the reduction of $\mathrm{Zn}^{+}$to $\mathrm{Zn}$. As it is known that the manganese reduction starts at more positive potential but here the reduction process is shifted to more negative potential because manganese metal ions are in the form of borate ligands. Hydrogen evolution is observed as it is seen for aqueous solution [20-22] and hence, those appeared peaks for reduction also include hydrogen reduction reaction.

The current line of the electrolyte having lower $\mathrm{pH}$ is different than higher $\mathrm{pH}$ (see Figure 2). This suggest that the mechanism of Zn-Mn deposition is significantly affected by the $\mathrm{pH}$ of deposition bath. As there is more free hydrogen ions $\left(\mathrm{H}^{+}\right)$in the electrolyte having low $\mathrm{pH}$, hydrogen evolution interfere with $\mathrm{Zn}$ and $\mathrm{Mn}$ reduction. This point could also be deduced from the area under oxidation peaks. The charge value (area under oxidation) of the deposition bath having higher $\mathrm{pH}$ is greater than that of lower $\mathrm{pH}$ because the current efficiency of alkaline electrolyte is higher than that of acidic electrolyte. The sum of zinc and manganese alloy reaction after $-1.5 \mathrm{~V}$ is given in Equation 1 . 


$$
\begin{aligned}
& \mathrm{xZn}\left(\mathrm{BO}_{3}\right)_{2}^{6-}{ }_{(a q)}+(1-\mathrm{x}) \mathrm{Mn}\left(\mathrm{BO}_{3}\right)_{2}^{6-}{ }_{(a q)}+2 \mathrm{e}^{-} \\
& \rightarrow\left(Z n_{x} M n_{(1-x)}\right)_{(s)}+2 \mathrm{BO}_{3}{ }^{4-}{ }_{(a q)}
\end{aligned}
$$

The negative potential limit illustrated in Figure 2 was selected as $-1.5 \mathrm{~V}$ because applied potential of potentiostatic deposition of the alloys in this study was $-1.5 \mathrm{~V}$. Both $\mathrm{Zn}$ and $\mathrm{Mn}$ have one broad oxidation peak at $-0.66 \mathrm{~V}$ and -0.45 $\mathrm{V}$ for acidic and basic electrolytes, respectively. The detail information about this could be found from EDAX analysis. Before presenting SEM and EDAX analyses, chronoamperogram of $\mathrm{Zn}-\mathrm{Mn}$ film deposition is illustrated in Figure 3.

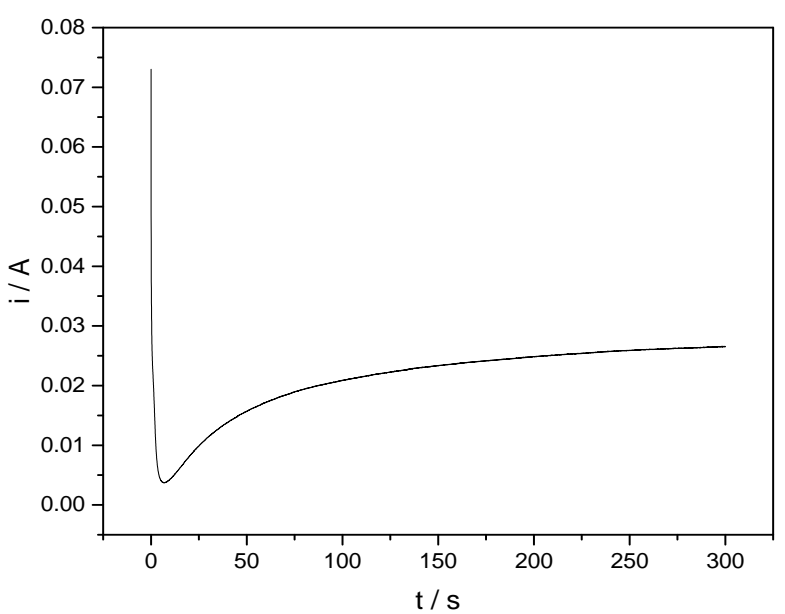

Fig-3: A representative chronoamperometric responses of $\mathrm{Zn}-\mathrm{Mn}$ film deposition onto carbon steel carried out in 50 $\mathrm{mM} \mathrm{ZnSO}_{4}+50 \mathrm{mM} \mathrm{MnSO}_{4}$ in $50 \mathrm{mM} \mathrm{H}_{3} \mathrm{BO}_{3}(\mathrm{pH}=7.12)$.

Chronoamperometry was performed applying a $-1.5 \mathrm{~V}$ vs. $\mathrm{Ag} / \mathrm{AgCl}$ reference electrode for 300 seconds.

Figure 3 illustrates that there is a sharp increase in current value (up to $74 \mathrm{~mA}$ ) at the beginning due to both hydrogen evolution and alloy deposition. As the alloy is deposited on the carbon steel, the current value decreases (until $5 \mathrm{~mA}$ ) because the surface now becomes $\mathrm{Zn}-\mathrm{Mn}$ alloy with carbon steel. Surface of the substrate evolves with time and reaches around $25 \mathrm{~mA}$. Zinc based alloy deposited on carbon steel also cause hydrogen reduction. Figure 3 shows that there is metal deposition competing with hydrogen evolution because it is not linear graph. If it was linear, it would mean that there is only hydrogen evolution. Hydrogen evolution on the new surface is less than that on carbon steel surface [23-25]. The films obtained potentiostatically applying -1.5 $\mathrm{V}$ for 300 seconds in different $\mathrm{pH}$ borate solutions were compared in terms of corrosion resistivity illustrated in section 3.2.2. Before that SEM and EDAX results of the films are presented to determine morphological and elemental analysis of coatings in terms of $\mathrm{pH}$ value of electrolyte.

\subsection{Characterisation of $\mathrm{Zn}-\mathrm{Mn}$ Coatings}

\subsubsection{Morphology of the Films}

The surface morphologies of the alloys are presented in Figure 4. EDAX analyses show that there is no trace of
Mnin the coatings obtained from the electrolytes having $\mathrm{pH}$ of 4.08 and 7.12. These films consist of $100 \% \mathrm{Zn}$. On the other hand, the film obtained from electrolyte of $10.2 \mathrm{pH}$ has $5.3 \mathrm{wt} \% \mathrm{Mn}$ and $94.7 \mathrm{wt} \% \mathrm{Zn}$. These results could be used to explain why there are three reduction peaks for alkaline media (black line of Figure 2) and only one peak for acidic media. These three peaks observed in alkaline media are due to the formation of manganese with zinc. However, there is only zinc coating in acidic media and one peak is seen (red line of Figure 2).

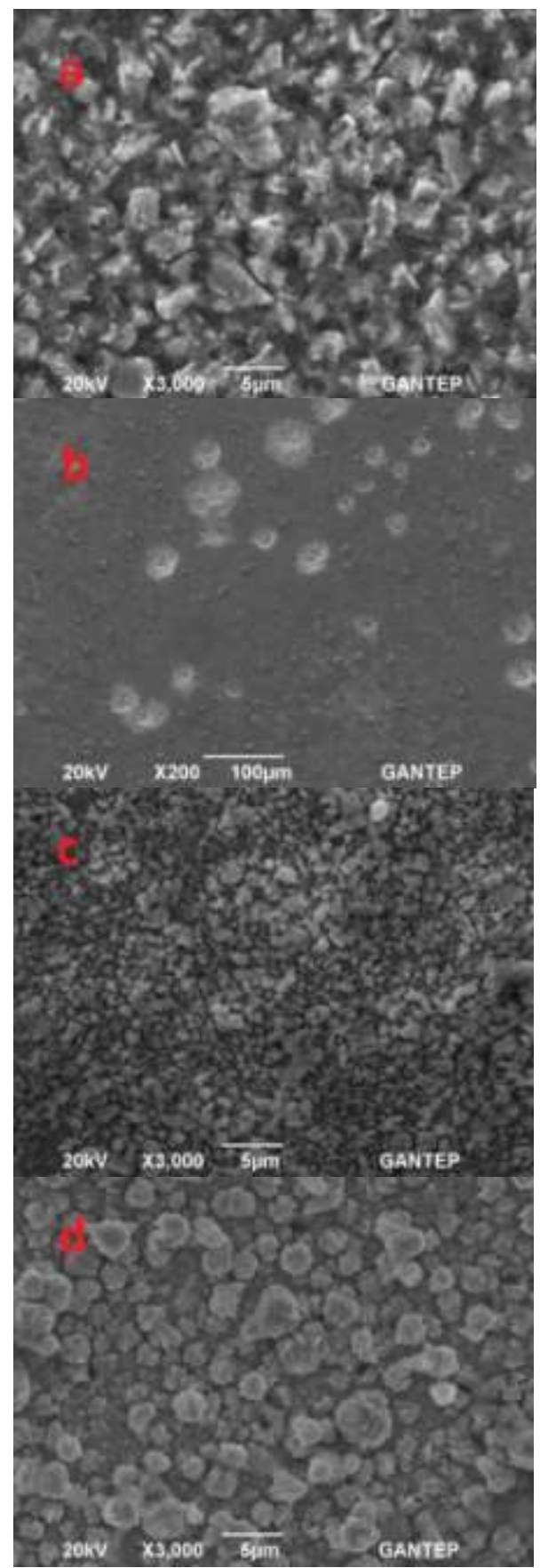

Fig-4: SEM images of the coatings on the carbon steel surfaces. The coatings were electrodeposited from borate medium including zinc and manganese sulphate solutions $\left(50 \mathrm{mM} \mathrm{ZnSO}_{4}+50 \mathrm{mM} \mathrm{MnSO}_{4}\right.$ in $50 \mathrm{mM} \mathrm{H}_{3} \mathrm{BO}_{3}$ ) with $\mathrm{pH}$ value of a) 4.08 ; b) 7.12 ; c) 10.2. d) only zinc coated carbon steel is given to compare the coatings with zinc. 
Panel a and panel b of Figure 4 consist of only zinc metals. However, their structures are different than each other. Panel d of Figure 4 is also only zinc coated steel which is given to compare the effect of electrolyte composition and electrolyte $\mathrm{pH}$. Zinc film electrodeposited from an electrolyte having only zinc sulphate (panel d of Figure 2) has crystalline hexagonal structure similar to the ones found in the literature [26-29]. However, zinc coating from borate bath whose $\mathrm{pH}$ is 4.08 has amorphous structure (Figure 4 a) and from the electrolyte whose $\mathrm{pH}$ is 7.12 is smoother than other films (panel b of Figure 4). As the coating deposited from $\mathrm{pH} 7.12$ is so smooth, higher magnification of it is presented here. Dissimilarities between zinc coatings occur due to different nucleation type formed in different $\mathrm{pH}$ and electrolyte. White and black area shown in each image in Figure 4 has no differences in terms of elemental analysis. The film obtained from the electrolyte having $\mathrm{pH} 10.2$ is in oval microspheres crystalline structure (Figure $4 \mathrm{c}$ ). This film is $\mathrm{Zn}-\mathrm{Mn}$ alloy which is the only alloy in this study. The crystal dimensions of the film shown in figure $4 \mathrm{c}$ are around $0.5 \mu \mathrm{m}$ X $1.5 \mu \mathrm{m}$. All films obtained from different $\mathrm{pH}$ media have crack free coatings. Electrolyte composition affects significantly the morphology of crystals. In order to correlate a probable relationship between structure and corrosion behaviour, section 3.2.2 examine the corrosion behaviour of the coatings.

\subsubsection{Corrosion Behaviour of the Films}

Polarisation potential of bare steel and coated steel in aqueous $\mathrm{NaCl}$ solution is presented in Figure 5 in order to compare corrosion passivation of the surfaces electrodeposited from boric acid media with bare carbon steel. The corresponding polarisation parameters derived from raw data of Figure 5 are measured and presented in Table 2.

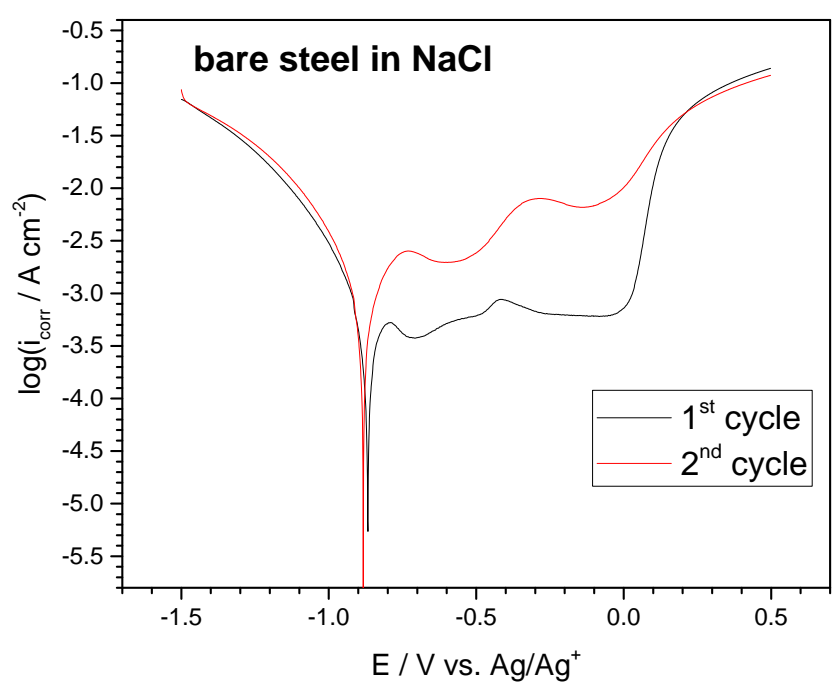

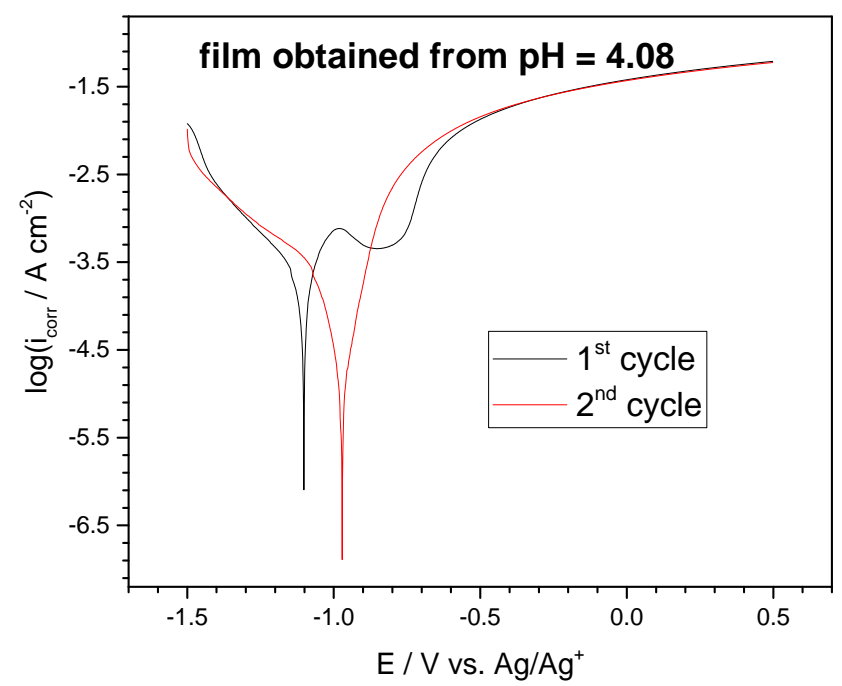
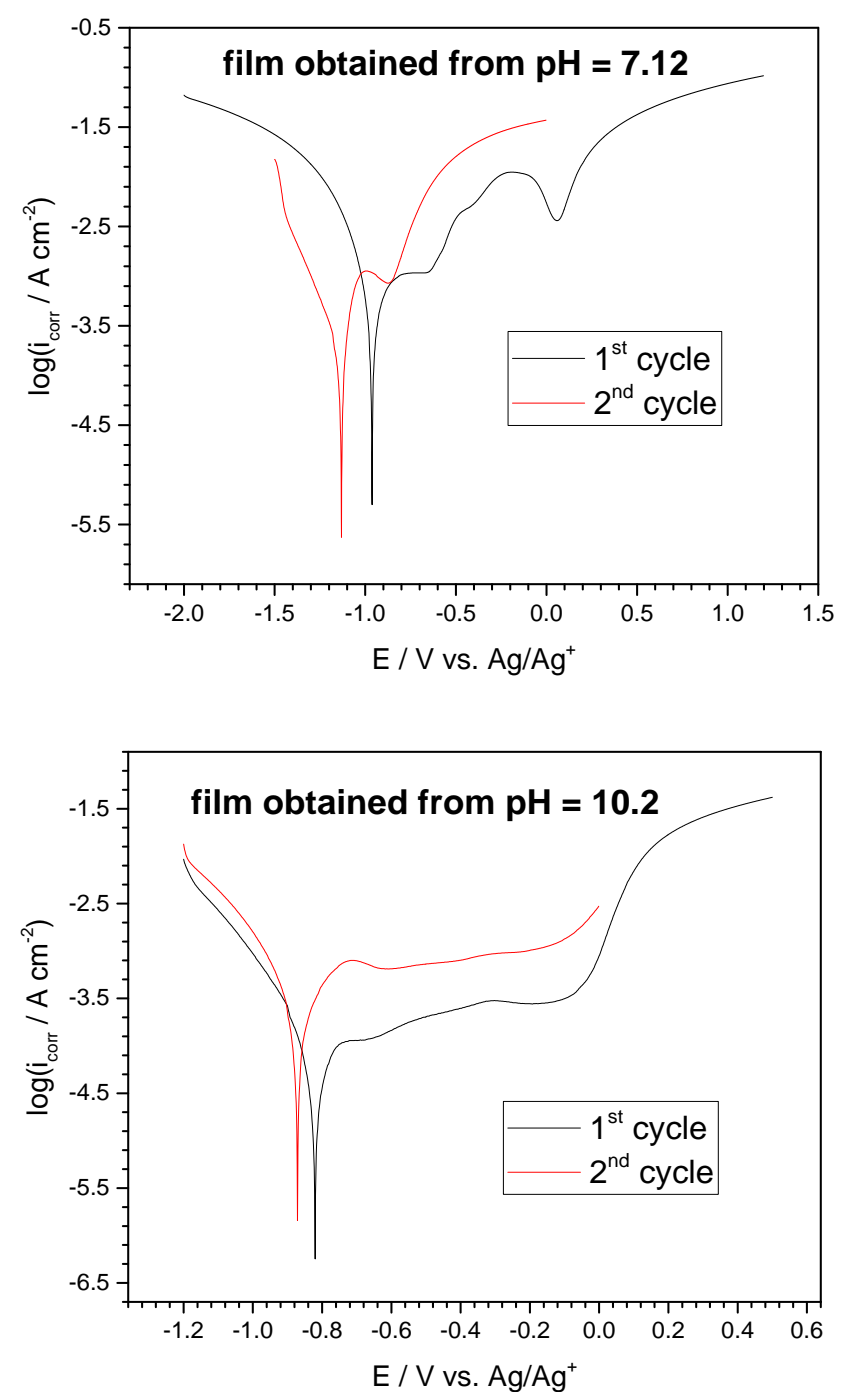

Fig-5: Potentiodynamic polarisation curves (Tafel plots) of a) steel substrate; and modified electrodes obtained from borate bath having a $\mathrm{pH}$ value of b) 4.08 ; c) 7.12 ; d) 10.2 in 3 wt. $\% \mathrm{NaCl}$ solution. 
The corrosion potentials of $\left(\mathrm{E}_{\mathrm{corr}}\right)$ of the films deposited from borate electrolyte are independent of electrolyte $\mathrm{pH}$. While $\mathrm{E}_{\text {corr }}$ of $\mathrm{pH} 10.2$ is lower $(-0.82 \mathrm{~V})$ than that of pure steel (-0.86), $\mathrm{E}_{\text {corr }}$ of alkaline and neutral deposition electrolyte are higher $-1.1 \mathrm{~V}$ and $-0.95 \mathrm{~V}$, respectively. $i_{\text {corr }}$ value current density of bare steel and zinc (also Zn-Mn) coated steel are close to each other between $49 \mu \mathrm{A} \mathrm{cm}^{-2}$ and $264 \mu \mathrm{A} \mathrm{cm}^{-2}$ given in Table 2 . However, $2^{\text {nd }}$ cycles in $\mathrm{NaCl}$ solution make significant difference between coated and uncoated steel. This is related to the pitting or passivation behaviour of materials.

Table 2: Electrochemical parameters of the corrosion potential $E_{\text {corr }}$, and corrosion current density $i_{\text {corr }}$ derived from the polarization curves given in Figure 5.

\begin{tabular}{|c|c|c|c|c|}
\hline Electrolyte & Pure steel & $\mathrm{pH}=4.08$ & $\mathrm{pH}=7.12$ & $\mathrm{pH}=10.2$ \\
\hline$i_{\text {corr }}\left(\mu \mathrm{A} \mathrm{cm}\right.$ cm $\left.^{-2}\right)$, the $1^{\text {st }}$ cycle & 167 & 209 & 264 & 49 \\
\hline$i_{\text {corr }}\left(\mu \mathrm{A} \mathrm{cm}\right.$ cm $\left.^{-2}\right)$, the $2^{\text {nd }}$ cycle & 1175 & 162 & 316 & 145 \\
\hline$E_{\text {corr }}(\mathrm{V}$ vs. $\mathrm{Ag} / \mathrm{AgCl})$, the $1^{\text {st }}$ cycle & -0.86 & -1.1 & -0.95 & -0.82 \\
\hline $\mathrm{E}_{\text {corr }}$ (V vs. Ag/AgCl), the $2^{\text {nd }}$ cycle & -0.88 & -0.97 & -1.1 & -0.85 \\
\hline
\end{tabular}

The corrosion rate of the $2^{\text {nd }}$ cycle of steel in aggressive environment increases more than 4 times with compare to that of the $1^{\text {st }}$ cycle., which is given in Table $2(1175 / 267=$ 4.4). The increase in current flow is also seen in panel a of Figure 1. Chloride solution accelerated pitting corrosion on steel surface. This can be analogous to an autocatalytical reaction. After coating of steel with either $\mathrm{Zn}$ or $\mathrm{Zn}-\mathrm{Mn}$ films from borate based solution, steel surface is prevented from pitting corrosion. Panel $\mathrm{b}$ of Figure 5 and Table 2 illustrate that the corrosion rate of the $2^{\text {nd }}$ cycle of the film obtained from $\mathrm{pH} 4.08$ decreases from $209 \mu \mathrm{A} \mathrm{cm} \mathrm{cm}^{-2}$ to 162 $\mu \mathrm{A} \mathrm{cm}^{-2}$ due to the passivation of surface. Corrosion rate of film deposited from $\mathrm{pH} 7.12$ electrolyte is not changed significantly after the $1^{\text {st }}$ scan in $\mathrm{NaCl}$ solution. Although corrosion rate of $2^{\text {nd }}$ scan for the $\mathrm{Zn}-\mathrm{Mn}$ alloy (for the $2^{\text {nd }}$ scan) electrodeposited from $\mathrm{pH} 10.2$ borate electrolyte is about 3 times more than that of $1^{\text {st }} \mathrm{scan}$, both corrosion rates for the $1^{\text {st }}$ and the $2^{\text {nd }}$ scans of $\mathrm{Zn}-\mathrm{Mn}$ coated steel are still much lower than those for bare steel. Better comparison of the $1^{\text {st }}$ and the $2^{\text {nd }}$ scans of the electrodes (bulk and modified electrodes) are given in Figure 6.

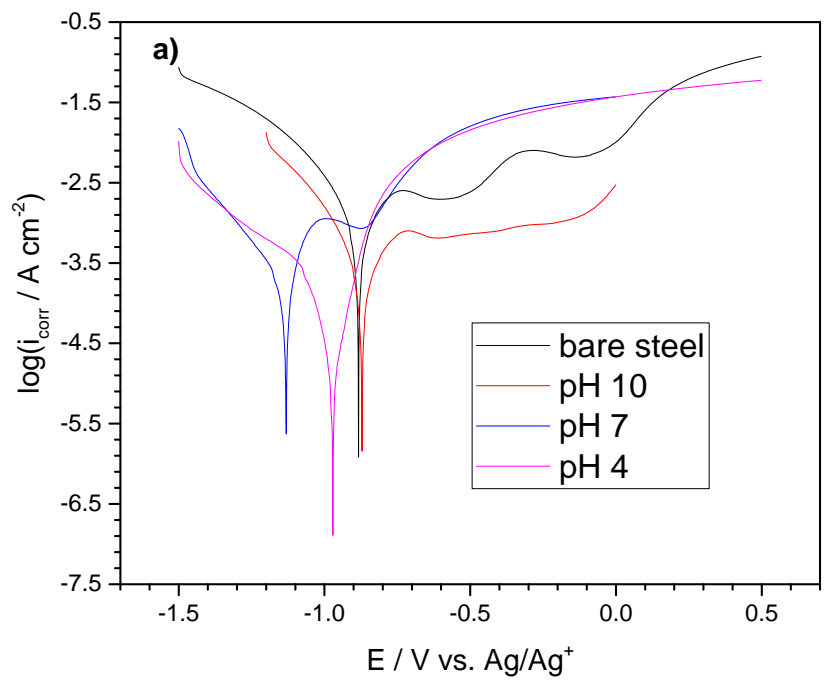

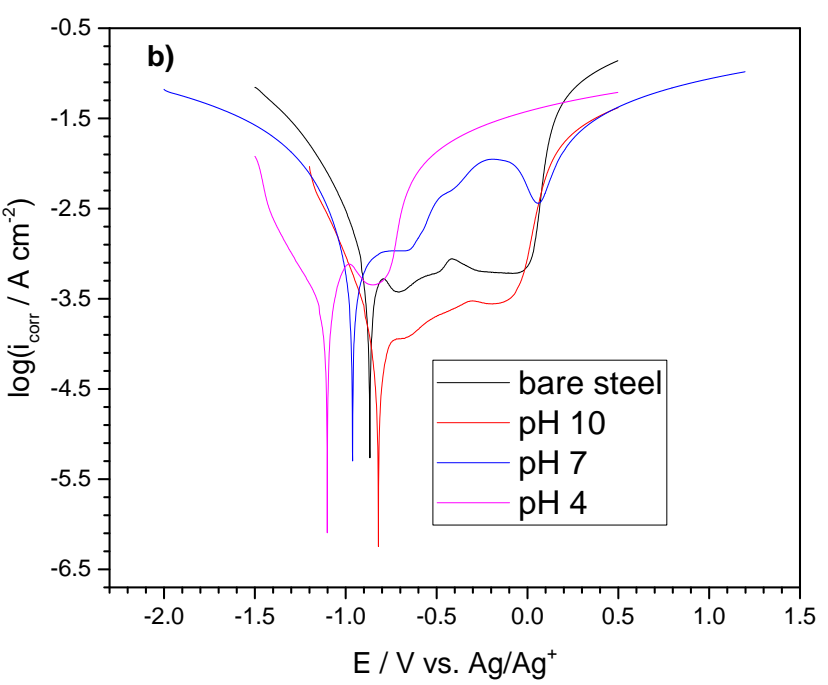

Fig-6: Potentio dynamic polarisation curves of uncoated and coated steel given in Figure 5 for a) the $1^{\text {st }}$ scans and; b) the $2^{\text {nd }}$ scans in $3 \mathrm{wt}$. $\% \mathrm{NaCl}$ solution.

Figure 6 and Table 2 illustrate clearly that the corrosion rate of bare steel is higher than all modified electrode. Therefore, electrodeposition of $\mathrm{Zn}$ and $\mathrm{Zn}-\mathrm{Mn}$ films from boric acid solution can not only protect steel from pitting corrosion but also give higher corrosion resistivity. The $2^{\text {nd }}$ scans of the films are much better for chloride based corrosive environment in comparison with bare steel as black line of Figure $6 \mathrm{~b}$ has highest $i_{\text {corr }}$ which is also seen in Table 2 . Among the coatings, $\mathrm{Zn}-\mathrm{Mn}$ film obtained from $\mathrm{pH} 10.2$ electrolyte has highest corrosion resistivity as its corrosion rate is $49 \mu \mathrm{A} \mathrm{cm}^{-2}$ which is 5.5 times better for corrosion protection of steel.

\section{CONCLUSION}

$\mathrm{Zn}$ metals and Zn-Mn alloys were deposited potentiostatically onto AISI 4140 steel by applying $-1.5 \mathrm{~V}$ for 300 seconds from borate electrolyte having different $\mathrm{pH}$ and the corrosion behaviours of the resultant coatings were elucidated. EDAX results showed that there was no reduction of manganese in acidic or neutral borate solution; 
hence, the coating from these solution contained only zinc. The film obtained from alkaline borate electrolyte was $\mathrm{Zn}$ Mn alloy including around 5wt. \% manganese. These results were used to explain why there is three reduction peaks in alkaline electrolyte and only one reduction peak in acidic electrolyte. Three peaks in alkaline bath are related to both $\mathrm{Zn}^{2+}$ and $\mathrm{Mn}^{2+}$ reduction mechanism in the alloy deposition. The only reduction peak in acidic electrolyte is associated with only zinc deposition (not trace of manganese). The current efficiency of metal deposition for explained conditions (the energy spent for coating rather than hydrogen evolution) is higher for alkaline solution than acidic solution.

Although the films deposited from acidic and neutral borate solution include only zinc coating, their surface morphologies are different than each other. While the film electrodeposited from acidic medium presents amorphous structure, the surface of the film obtained from neutral bath is smooth and has crystalline structure. Normally, zinc coating without $\mathrm{Mn}^{2+}$ addition to the deposition solution has hexagonal crystalline structure (shown by SEM image as well), the films with $\mathrm{Mn}^{2+}$ addition cause a different surface than hexagonal crystalline $\mathrm{Zn}$ surface as electrolyte composition cause the change of the structure. The $\mathrm{Zn}-\mathrm{Mn}$ alloy deposited from alkaline borate bath has oval microspheres around $1.0 \pm 0.5 \mu \mathrm{m}$.

The corrosion potentials $\left(\mathrm{E}_{\mathrm{corr}}\right)$ of the films deposited from borate electrolyte are independent of the value of deposition $\mathrm{pH}$. Although $\mathrm{i}_{\text {corr }}$ value of bare steel and zinc (also $\mathrm{Zn}-\mathrm{Mn}$ ) coated steel are close to each other for the $1^{\text {st }}$ cycle in $\mathrm{NaCl}$ solution, the $2^{\text {nd }}$ cycles in $\mathrm{NaCl}$ solution make a significant difference between coated and uncoated steel. The corrosion rate of the $2^{\text {nd }}$ cycle of steel in $\mathrm{NaCl}$ solution increases more than 4 times with comparison to that of the $1^{\text {st }}$ cycle. Chloride solution accelerated the pitting corrosion on steel surface due to an autocatalytical reaction. After coating of steel with either $\mathrm{Zn}$ or $\mathrm{Zn}-\mathrm{Mn}$ films from borate based solution, steel surface is prevented from pitting corrosion. Corrosion rate of film deposited from pH 7.12 electrolyte is not changed significantly after the $1^{\text {st }}$ scan in $\mathrm{NaCl}$ solution. Although corrosion rate of the $2^{\text {nd }}$ scan for the $\mathrm{Zn}-\mathrm{Mn}$ alloy (for the $2^{\text {nd }}$ scan) electrodeposited from $\mathrm{pH} 10.2$ borate electrolyte is about 3 times more than that of the $1^{\text {st }}$ scan, both corrosion rates for the $1^{\text {st }}$ and the $2^{\text {nd }}$ scans of $\mathrm{Zn}-\mathrm{Mn}$ coated steel are still much lower than those for bare steel. Corrosion rate of bare steel is higher than that of all modified electrode. Therefore, electrodeposition of $\mathrm{Zn}$ and $\mathrm{Zn}-\mathrm{Mn}$ films from boric acid solution can not only protect steel from pitting corrosion but also give higher corrosion resistivity. The $2^{\text {nd }}$ scans of the films are much better for chloride based corrosive environment compare with bare steel as zinc metal and $\mathrm{Zn}-\mathrm{Mn}$ alloy coatings cause passivation of surface. Among the coatings, $\mathrm{Zn}-\mathrm{Mn}$ film obtained from alkaline electrolyte has highest corrosion resistivity as its corrosion rate is $49 \mu \mathrm{A} \mathrm{cm}^{-2}$ (more than 5 times better for corrosion protection of steel than bare steel).

\section{ACKNOWLEDGEMENT}

This study is supported by University of Gaziantep, Scientific Research Projects Unit (BAPYB) by a research project number of MF.YLT.1608. The Authors would like to thank to Food Products R\&D Centre, Gaziantep University.

\section{REFERENCES}

[1]. Kangas P. High Temperature Corrosion Problems in Refineries, Chemical Process Industries and Petrochemical Plants. High Temperature Corrosion: World Scientific; 2016. p. 87-98.

[2]. Isimjan TT, Wang T, Rohani S. A novel method to prepare superhydrophobic, UV resistance and anti-corrosion steel surface. Chemical Engineering Journal. 2012;210:1827.

[3]. Haciibrahimoglu M, Yavuz A, Oztas M, Bedir M. Electrochemical and structural study of zinc-rich brass deposited from pyrophosphate electrolyte onto the carbon steel. Digest Journal of Nanomaterials and Biostructures. 2016;25:4680-5.

[4]. Kasai N, Kaku Y, Okazaki S, Hirai K. Mechanism for Corrosion Prevention by a Mechanical Plating of Uniform Zinc-Iron Alloy. Journal of Materials Engineering and Performance. 2016;25:4680-5.

[5]. Qiao X, Li H, Zhao W, Li D. Effects of deposition temperature on electrodeposition of zinc-nickel alloy coatings. Electrochimica Acta. 2013;89:771-7.

[6]. Haciibrahimoglu M, Bedir M, Oztas M, Cakez C. Structural and the corrosion characteristic study of AZ91 alloy with and without $\mathrm{CuZn}$ coating in\% $3 \mathrm{NaCl}$ solution. Digest Journal of Nanomaterials and Biostructures. 2015;10:1439-47.

[7]. Bedir M, Korkmaz D, Bakkaloglu OF, Oztas M, Karahan İH, Haciibrahimoglu MY. Effect of pH Values on the Characterization of Electrodeposited $\mathrm{Zn}-\mathrm{Mn}$ Coatings in Chloride-Based Acidic Environment. International Journal of Electrochemical Science. 2015;10:4513-22.

[8]. Koleva D, Boshkov N, Raichevski G, Veleva L. Electrochemical corrosion behaviour and surface morphology of electrodeposited zinc, zinc-cobalt and their composite coatings. Transactions of the IMF. 2013.

[9]. Ortiz Z, Díaz-Arista P, Meas Y, Ortega-Borges R, Trejo G. Characterization of the corrosion products of electrodeposited $\mathrm{Zn}, \mathrm{Zn}-\mathrm{Co}$ and $\mathrm{Zn}-\mathrm{Mn}$ alloys coatings. Corrosion Science. 2009;51:2703-15.

[10]. Fashu S, Gu C, Zhang J, Zheng H, Wang X, Tu J. Electrodeposition, morphology, composition, and corrosion performance of $\mathrm{Zn}-\mathrm{Mn}$ coatings from a deep eutectic solvent. Journal of Materials Engineering and Performance. 2015;24:434-44.

[11]. Chen P-Y, Hussey CL. The electrodeposition of Mn and $\mathrm{Zn}-\mathrm{Mn}$ alloys from the room-temperature tri-1butylmethylammonium bis ((trifluoromethane) sulfonyl) imide ionic liquid. Electrochimica Acta. 2007;52:1857-64.

[12]. Chen K, Wilcox GD. Tin-manganese alloy electrodeposits I. Electrodeposition and microstructural characterization. Journal of the Electrochemical Society. 2006;153:C634-C40. 
[13]. Sylla D, Savall C, Gadouleau M, Rebere C, Creus J, Refait P. Electrodeposition of Zn-Mn alloys on steel using an alkaline pyrophosphate-based electrolytic bath. Surface and Coatings Technology. 2005;200:2137-45.

[14]. Selvam M, Guruviah S. Electrodeposition of zincmanganese alloy from sulphate-citrate bath. Bulletin of Electrochemistry. 1989;5:352-8.

[15]. Savall C, Rebere C, Sylla D, Gadouleau M, Refait P, Creus J. Morphological and structural characterisation of electrodeposited $\mathrm{Zn}-\mathrm{Mn}$ alloys from acidic chloride bath. Materials Science and Engineering: A. 2006;430:165-71.

[16]. Griskonis E, Sulcius A. Influence of selenates on the electrodeposition of zinc-manganese alloy. Bulletin of Electrochemistry. 2005;21:561.

[17]. Bozzini B, Griskonis E, Fanigliulo A, Sulcius A. Electrodeposition of $\mathrm{Zn}-\mathrm{Mn}$ alloys in the presence of thiocarbamide. Surface and Coatings Technology. 2002;154:294-303.

[18]. Eliaz N, Sridhar T, Gileadi E. Synthesis and characterization of nickel tungsten alloys by electrodeposition. Electrochimica Acta. 2005;50:2893-904.

[19]. Wu C, Zhang Z, Cao F, Zhang L, Zhang J, Cao C. Study on the anodizing of AZ31 magnesium alloys in alkaline borate solutions. Applied Surface Science. 2007;253:3893-8.

[20]. Zhang N, Ma W, Jia F, Wu T, Han D, Niu L. Controlled electrodeposition of CoMoS x on carbon cloth: A 3D cathode for highly-efficient electrocatalytic hydrogen evolution. International Journal of Hydrogen Energy. 2016;41:3811-9.

[21]. Lupi C, Dell'Era A, Pasquali M. Nickel-cobalt electrodeposited alloys for hydrogen evolution in alkaline media. International Journal of Hydrogen Energy. 2009;34:2101-6.

[22]. Pillai IMS, Gupta AK. Potentiostatic electrodeposition of a novel cost effective $\mathrm{PbO} 2$ electrode: degradation study with emphasis on current efficiency and energy consumption. Journal of Electroanalytical Chemistry. 2015;749:16-25.

[23]. Hsieh M-T, Chen C-T, Whang T-J. Triethanolaminefacilitated one-step electrodeposition of CuAlSe 2 thin films and the mechanistic studies utilizing cyclic voltammetry. Journal of Electroanalytical Chemistry. 2016;762:73-9.

[24]. Lee H, Lee J-H, Hwang Y-H, Kim Y. Cyclic voltammetry study of electrodeposition of $\mathrm{CuGaSe} 2$ thin films on ITO-glass substrates. Current Applied Physics. 2014;14:18-22.

[25]. Abbott AP, Ballantyne A, Harris RC, Juma JA, Ryder KS. A comparative study of nickel electrodeposition using deep eutectic solvents and aqueous solutions. Electrochimica Acta. 2015;176:718-26. 